\title{
THE BIRTH OF THE CZECH MALL ENTHUSIAST: THE TRANSITION OF SHOPPING HABITS FROM UTILITARIAN TO LEISURE SHOPPING
}

\begin{abstract}
SPILKOVÁ, J. (2012): The Birth of the Czech Mall Enthusiast: The Transition of Shopping Habits From Utilitarian to Leisure Shopping. Geografie, 117, No. 1, pp. 21-32. - During the 1990s, shopping habits and consumer behavior underwent many important changes in Czechia. Consumers started to prefer large retail outlets and shopping malls, and began to shop less frequently. Shopping has become not only an act of utilitarian economic exchange, but also a leisure activity. This article introduces the results of a pilot study aimed at mapping the volume of leisure shopping within Czech society. The majority of respondents visit shopping malls regularly and three main groups of shoppers may be constructed, based on analysis of the survey responses: (i) mall enthusiasts, (ii) indifferent mall goers, and (iii) mall opposers. On the whole, Czech consumers have quickly accepted the characteristics and trends of developed economies along with "western" models of shopping. However, shopping does not present a legitimate alternative to traditional leisure activities. KEY WORDS: shopping behavior - shopping mall - leisure shopping - Czechia.
\end{abstract}

The article is based on research undertaken within research project no. MSM 0021620831 "Geographical Systems and Risk Processes in the Context of Global Changes and European Integration", sponsored by the Czech Ministry of Education, Youth and Sport, project No. 205/08/P190 and project No. 404/12/0470 sponsored by the Czech Science Foundation.

\section{Introduction}

The 1990s brought many significant societal and economic changes to Czech society. Democratization and the return to a market-oriented economy were among the most important. Retailing in the nineties could be characterized by the dissolution of state-owned companies, newly emerged business companies, transfers in property, foreign direct investment inflows, growth in leaseable areas, increasing numbers of employees in retailing and services and a thorough modernization of the whole retail landscape.

The second half of the 1990s also ushered in significant changes in the population's shopping and consumer behavior. It is necessary to understand that in just short time of the two decades retail development in Czechia skipped over perhaps 50 years of normal retail development. This accelerated growth has also had a strong influence not only on its spatial structure (Szczyrba 2005), but also on consumer behavior, which had under the communist regime followed a different development pattern marked with certain lack and lower quality of shopping opportunities. Current consumption and shopping behavior has thus transformed into a certain kind of leisure activity in contemporary Czech society. 
This article aims to map the extent of the leisure shopping phenomenon within the current Czech consumer society. After a short description of the development of shopping behavior in the $1990 \mathrm{~s}$, a theoretical background describing the features of leisure shopping is presented. In the next part of the article, the results of a pilot survey are introduced. The attitudes toward to shopping as a leisure activity and the meaning of shopping malls in the lives of young, mainly urban Czech people were analysed by the means of both quantitative and qualitative analysis. The transitional state of Czech leisure shoppers is discussed in the concluding section.

\section{Changes in the behavior of Czech shoppers in the transformational period}

The changing behavior of Czech shoppers can be further reflected in the monitoring of shopping format preferences. This survey is periodically conducted by the company INCOMA Research. In Figure 1, gradual changes in shopping preferences are indicated, shifting from the preference of typical shopping formats associated with the former period (smaller self-service stores, convenience stores) to the newly emerged large-scale shopping formats. It is important to note that in this group of large-scale formats, the smaller types, such as supermarkets, prevailed until the year 2000 (Spilková 2008).

The supermarkets started to be confronted by the growing pressure of hypermarkets that have been increasingly preferred by customers (especially those with a car) since approximately 2000. Their number grew only slowly (in 1995 there were no hypermarkets in Czechia), however their growth intensified in 2000 . What is more, the preference for hypermarkets rose significantly in the same period, from $20 \%$ of shoppers in 2000 to $29 \%$ in 2001 . The preference for hypermarkets culminated in 2003 when the hypermarket was the main shopping place for $37 \%$ of the surveyed customers. Czechia is currently the country with the highest number of hypermarkets per million inhabitants in Central Europe (AC Nielsen 2006).

At the same time, a new important agent in the form of the discount store entered the competition among the retail formats. 2003 was the first year when discount stores and supermarkets accounted for the same percentage of customers. Since 2003, the supermarket format has been defeated by the discount store which has continuously been gaining in importance in terms of customer preference. By the end of 2005, the discount store was the most preferred shopping place for $24 \%$ of Czech customers (Spilková 2008).

This trend of preferences for larger outlets has tended to continue. In 2010, the hypermarket was the main shopping place for $43 \%$ of Czech households, $25 \%$ stated the discount store to be their main shopping place, for $15 \%$ it was the supermarket and another $15 \%$ chose the small convenience store. Preferences for the particular retail formats obviously corelate with the settlement structure and the possibilities offered by the retail net in the particular region, but also with social and demographic profile of the shoppers (households and families respectively). Hypermarkets are preferred by the higher educated peo-

ple and shoppers consisting of families with children. The highest preference of hypermarkets is found in big cities, on the contrary, in the smaller cities they 


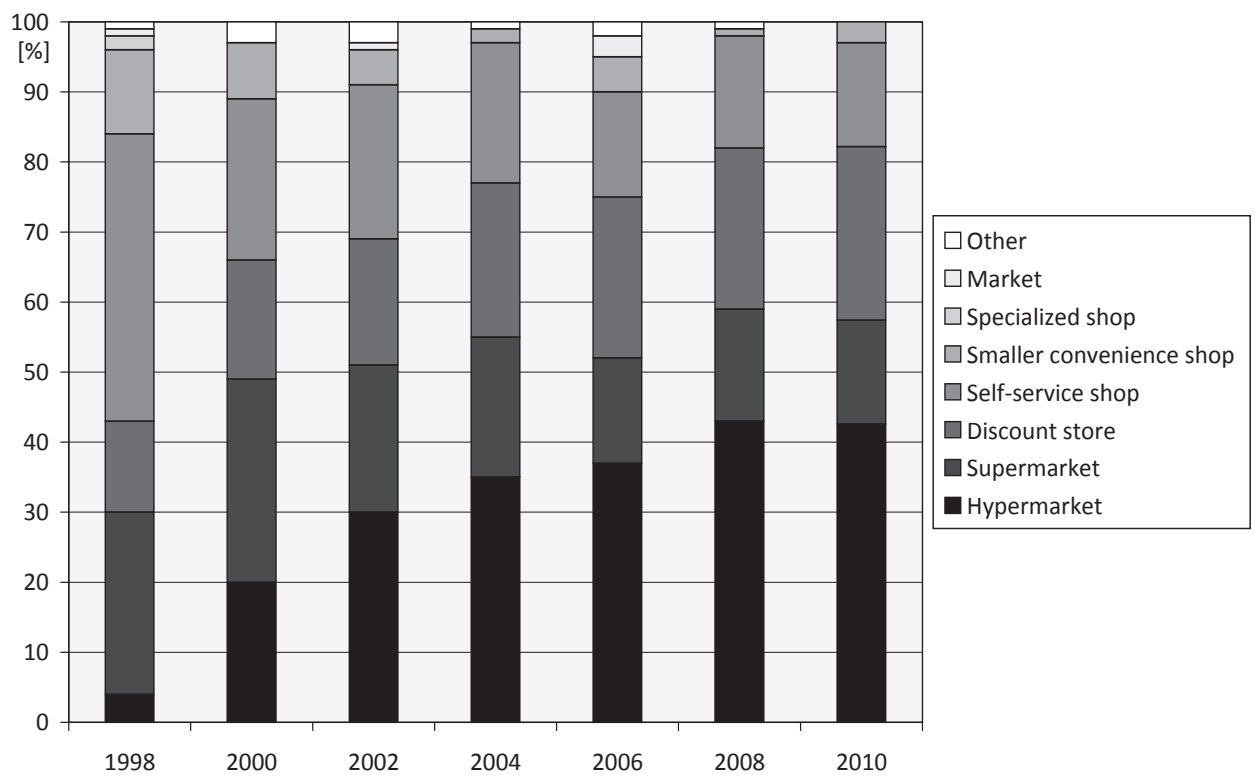

Fig. 1 - Preference for the Main Shopping Destination in 1998-2010. This figure depicts the changing preference for the main shopping place for the Czech consumers in the period between 1998 when large-scale retail formats started to grow and 2010. The shift to large-scale and more complex facilities is obvious and popularity of the traditional, smaller retail forms declines. Source: INCOMA Research, GfK Prague.

are replaced by discount stores. Highly mobile customers also tend to use the hypermarkets for shopping. Discount stores are the favorite outlets of people from the middle sized cities (5-20,000 inhabitants) while income seems to influence the preference of discount stores only marginally. Discounts have a strong position mainly in the central, western and eastern parts of Czechia. Supermarkets are favored by the people from larger cities, but other sociodemographic characteristics do not seem to be significant. It can be concluded that supermarkets serve as a complementary shopping place for everyday shopping and are used thanks to the proximity to the shopper's place of residence. Smaller self-service shops are chosen by people lower incomes and who reside in smaller municipalities (up to 5,000 inhabitants), thus this group represents people from the settlements where the choice of other retail formats seems to be rather limited (Shopping Monitor 2005/6).

Another new retail format is represented by the shopping center (Spilková 2003). At the beginning of 2003, there were some 127 shopping centers and in 2010 there were already 250 large shopping malls with more than 5,000 square meters, of which more than eighty are malls with more than 50 tenants. The current trend may be characterized by the development of more luxury and life style oriented malls and also by increase in their volume and scale.

The development of large retail facilities is undisputably related to changes in the shopping behavior of Czech customers. In general, the frequency of shopping is declining, shifting to so-called "weekly" shopping. An increasing proportion of the population uses a car when shopping (approximately 60\%). 
According to Shopping Monitor 2005/6, Czechs like to shop, they do not mind the time spent in shops and they carefully choose the shops they visit. Another foreign market survey (The Future Foundation 2006) state that Czechs have a high shopping IQ, especially in comparison to other Central European nations / especially in comparison to the other former Eastern Bloc countries, thus they are economical and they are able to gather the necessary information before purchasing. It is therefore clear that Czechs accept "western" modes of behavior more quickly than the rest of the Central European nations. They also tend to use the car more, they attach more importance to retailers' leaflets and they are more sensitive to advertising in general (The Future Foundation 2006).

Another aspect of the above-mentioned change in shopping behavior is the fact that shopping became a form of relaxation or leisure activity (Newby 1993, Spilková 2003, Timothy 2005). Shopping malls represent the preferred destination of weekend family trips. This trend is called "fun shopping" or "experience" shopping. Shopping is not only an act of utilitarian economic exchange in this respect; on the contrary, it becomes a leisure activity. Shopping malls turn into business and also social centers with their supply of entertainment, relaxation, sport facilities etc. The surveys show that more than one quarter of shoppers spend more than two hours weekly and another half of the shoppers spends one to two hours weekly in their favorite mall (Shopping Mall 2007). Only a minority of shoppers spend less than one hour in a shopping mall per week. It is apparent from the surveys that most of this time is spent in the large complex shopping centers, with shopping galleries, complementary services, food courts, multiplexes etc.

\section{Typologies of shopping and shoppers}

Shopping behavior is a traditional topic not only in marketing theories (Brewis-Levie, Harris 2000; Sojka, Giese 2003), but also in social geography or sociology. Consumer activity and its spatial representation (where the customer shops) has a close relation to the organization of the retail system and to the localization of particular outlets. It is also widely recognized that the explanation of consumer patronage sometimes lies in the subjective variables (image of the mall, subjective distance, preference, trust) rather than in objective variables such as the actual distance, accessibility or price level (Dennis et al. 2002; Gilboa, Rafaeli 2003). Thus, shoppers are not only rational actors, but they are also attracted to shopping and particular outlets by factors such as the quality of service, friendly environment, image, atmosphere etc. (Spilková 2002).

There are many classifications of shoppers which have developed during the last five decades and incorporated different and more complex features each time (Bloch, Ridgway, Dawson 1994; Finn, McQuity, Rigby 1994; Kotler 1965; Lesser, Hughes 1986; Stone 1954 etc.). However, we turn to the typology of shopping rather than the classification of shoppers. Often, a classification denoting the purpose of shopping is used. Guy (1998) differentiates between convenience shopping (aimed at large supermarkets or food stores), household shopping (realized often in big shopping centers), and personal/fashion shopping (focused 
on browsing and the comparison of goods in shopping galleries). Consequently, he mentions leisure shopping, concentrated inshopping malls or factory outlet centers. Incidental shopping is characteristic for travelling persons and commuters and it is practiced in the smaller shops in transport terminals etc. Sometimes, an abbreviated classification is used, discerning between purpose (or even multipurpose) and leisure shopping only.

Purpose shopping tends to be planned ahead and price oriented. It differs substantially between men and women (Underhlill 1999). Purpose shopping may also be a source of frustration, for example, when the shopper does not have enough information or faces some obstacles while shopping or experiences boredom (Timothy 2005). On the contrary, leisure shopping should be entertaining. In this respect, the goal is not only to buy a particular product, but also to satisfy other needs - social interaction, fun, new stimuli etc.

Leisure shoppers do not come into the mall with a clear idea of what they want. They are sensitive to the mall environment and complementary service duality. They like to shop in groups or with friends and relatives, and they continue shopping after the purchase has been made. An important part of leisure shopping is formed by so called impulsive shopping. This is defined as the decision to make a purchase after the moment when a shopper enters the store (Bellenger, Robertson, Hirschman 1978).

Leisure shopping, thus referring to shopping without a clear intention to purchase, is not, however, a new topic in sociology or marketing. It is interesting to mention that some of the first works of the Chicago school had already dealt with the phenomenon of social networks, which are created in the cities as a defence to the disaffection brought on by the urban environment (Wirth 1938). Stone (1954) claims that people who miss social contacts on the neighborhood level compensate this lack by socialization while shopping. In this context, an interesting role is played by the shopping malls when also studying elderly populations. More often, elderly people use shopping malls to satisfy their need for social contact and physical exercise at the same time (Graham et al. 1991). The same is true for the leisure time spent in malls by young people and teenagers (Baker, Haytko 2000; Thomas 2005; Wilhelm, Mottner 2005). Thus the study of shopping behavior is very close to similar sociological surveys or surveys on the leisure activities of the population.

\section{Leisure shopping in Czechia: the results of a questionnaire survey}

As stated above, the trend of fun shopping has already emerged to a larger extent among Czech consumers. Following the theoretical background on the growing preference of large retail outlets and shopping malls and the accentuation of leisure shopping, a study conducted in the summer of 2010 is presented. This study aimed to map the volume of the leisure shopping phenomenon within Czech society, to reveal if shopping represents a relevant form of leisure activity and to sketch out the characteristics of consumers who consider shopping as a prime leisure activity.

The methodology of data gathering was based on the snowball method and the self-selection method which can be upon the fulfillment of certain conditions 
considered as representative sampling methods ${ }^{1}$ (Reichel 2009, p. 83). The distribution of the questionnaire was realized via internet, despite the fact that some authors criticize internet surveys as exclusive for the people without computer, internet connection or without the will to take part in the survey (De Vaus 2002). Despite this issue, even De Vaus (2002) claims that in some cases the internet survey may become a usefull tool to approach specific populations of interest. The questionnaire was created in the on-line web page application dedicated to survey conducting with its own web hosting. The inbuilt programming also allows viewing the first descriptive statistics of the conducted survey and offers the possibility to display the results of the survey on-line to the respondents or other interested individuals.

\subsection{The Questionnaire}

The survey was realized by the means of internet questioning. The questionnaire contained questions on the preference of retail formats, on shopping in malls and important factors influencing the consumers' choice of a particular mall, as well asquestions on the topic of leisure time. One part of the questionnaire was also devoted to open questions on the attitudes of respondents to shopping and shopping malls, their emotive response to shopping malls and the meaning of shopping in their lives. Questions mapping socio-demographic characteristics of respondents were also included. The multi-choice questions were analysed by the means of quantitative statistic analysis in the statistical software SPSS 16.0 and the open questions were subjected to text analysis (Flick et al., von Kardoff, Steinke 2004), creating three major categories of attitudes to shopping. Pretesting of the questionnaire revealed a need for revision so that the questionnaires were easier to understand, mainly in the section concerned with the emotional response to shopping malls. The response rate of the revised questionnaire was $26 \%$ and altogether 224 respondents were included in the survey.

\subsection{The Sample Population}

The sample population shows some deviations mainly from the point of view of gender, as $79 \%$ of the respondents were women and only $21 \%$ men. Nevertheless, due to the fact that the majority of household shopping is done by women, this result does not have to mean a threat to the orientation character of the study. It was aimed to target mainly younger people and middle-aged consumers who constitute the dynamics of the consumer society. $28 \%$ of respondents were in the age group from 16 to 20 years, $47 \%$ were in the age group from 21 to 30 years. Approximately 44\% lived in cities with more than 100,000 inhabitants

1 From certain point of view (for example in relation to the particular group under study) these samples may be considered as representative, however, what matters is the object of study. Sometimes, it is not representativeness in the rigid statistical sense rather than representativeness (or dominance) of ideas, reasons or, in the expert surveys, representativeness of the problem field (Reichel 2009, p. 83). Within this prism, the presented sample can be considered as adequately representative for the purpose of the pilot study. 
and other settlement categories were evenly distributed (always between seven and $10 \%$ ), $23 \%$ of respondents were from the capital city of Prague. Roughly $34 \%$ of respondents lived in families of four members, one fourth of the respondents lived in families with three members, $22 \%$ lived in two-member families and $7 \%$ of respondents lived alone. $68 \%$ of respondents lived in families without children up to 15 years, $19 \%$ in families with one child and $10 \%$ in families with two children up to 15 years. Thus, it is assumed that the respondents were mainly younger people, living in bigger cities, living with parents or with a partner, without children or with one or two children in the household. This population thus corresponds with the characteristics of potential leisure shoppers, or groups who will (after the achievement of economic freedom) represent a base from which new leisure shoppers may be recruited.

It is interesting to note that some $42 \%$ of the respondents replied that they spent their leisure time passively (relaxing or watching TV) and $24 \%$ spent their leisure time actively, another $14 \%$ of respondents dedicated their time to some kind of specific hobby. Six percent of the surveyed consumers stated that they prefer to spend their leisure time by shopping. Only five percent of the total claimed that they do not go shopping in shopping malls. Others visit shopping malls mostly two to four times a month (33\%), once a week (29\%), or once a month (24\%). They spend approximately two hours there in most cases (37\%), about one hour in $21 \%$ of cases and $15 \%$ of the respondents spend on average three hours in their favorite shopping mall per visit.

For $69 \%$ the shopping mall is mainly a place where they can buy all they need, where they have a good choice and the possibility to compare goods and prices (61\%), a place with quality shops (55\%). Roughly the same importance has been assigned to categories of accessibility by car (43\%), to the fact that there are clean toilets, refreshment kiosks and a clean environment (always about $40 \%$ ), accessibility by public transport and reasonable prices (both $39 \%$ ). One fourth of the surveyed stated that the shopping mall is a place which they enjoy and they like to spend their time there and $13 \%$ of respondents consider a shopping mall to be a lively, exciting place.

Despite the fact that the results of the study can be considered only for the depiction of current trends, it is clear that Czech consumers are still somewhere in transition between the two phases of shopping behavior formation (Spilková 2003). They are fully adapted to the new retail environment with large-scale outlets, to the lower frequency of shopping and to large, complex shopping malls which were converted into places of social encounters and leisure acitivities. Nevertheless, they still appreciate mainly the utilitarian characteristics of the shopping malls (such as one-stop shopping, choice, accessiblity by car and public transport, services etc.). However, we can clearly distinguish a group of shoppers who consider shopping more than just an exchange activity, for whom shopping is a leisure activity, a life style, and for whom the shopping mall becomes the natural centre of their action space.

\subsection{Quantitative Analysis}

The quantitative analysis started with the search for significant differences between particular groups of shoppers. However, the analysis did not reveal 
many statistically significant and strong relations, which depict the situation when Czech society is equally distributed according to questions of shopping, shopping mall preferences and leisure activities. No significant differences are evidenced between the frequency of mall visits and the settlement size, due to the fact that smaller shopping malls are already being located also in the smaller cities (20 to 50,000 inhabitants) and inhabitants from smaller settlements can easily reach a shopping mall in an adjacent city within a dense Czech settlement network. Similarly, leisure activity according to the settlement size is homogenized showing the fact that there are no significant differences between the lifestyles of urban and rural dwellers. There is no significant difference in the frequency of mall visits between men and women, which testifies that across gender we can find both enthusiastic shoppers and those who hate shopping in large premises. Neveretheless, there is a significant statistical difference in leisure time activities according to gender $(p<0.024)$, where it is no surprise that women are those who spend their time shopping for leisure more often than men ( $86 \%$ vs $14 \%$ ). There are also interesting differences in the time spent in the mall according to preferred leisure activity $(p<0.05)$. Dedicated leisure shoppers spend more than four hours in the mall, the least time in the mall is spent by people with specific hobbies (however, even in this case the average time reached 1.8 hour).

It is also interesting to observe the differences in the time spent in the mall according to age $(p<0.05)$. With increasing age the time spent in the mall decreases. The longest average time was reported by the respondents up to 16 years (2.8 hour) which clearly testifies to the existence of the "mall junkies" phenomenon in Czech malls (Baker, Haytko 2000; Kowinski 1985; Thomas 2005; Underhill 2004; Wilhelm, Mottner 2005; Spilková, Radová 2011). Of further interest is that the time spent in the mall increases with the decreasing size of the residence $(p<0.05)$. In the cities with 100,000 and more inhabitants, people spend on average 1.88 hour in the mall, in the rank of 50-100,000 inhabitants it was 1.96 hour, in the cities with 20 to 50,000 inhabitants the time spent in the mall reaches 2.15 hour, 2.63 hour for the people from towns with 10 to 20,000 inhabitants and consumers from towns with five to 1,000 inhabitants spend on average 3.02 hour in their favorite mall. This sequence was not confirmed for smaller towns where the time decreases to 2.27 hour and 2.25 hour for residence with one to five thousand inhabitants (resp. settlements smaller than 1,000 inhabitants). A similar relation is also found in the analysis of the time spent in the mall according to the region of residence $(\mathrm{p}<0.05)$, whereby it can be concluded that consumers from peripheral regions tend to spend more time in shopping malls, however, with a lower frequency of visits.

\subsection{Qualitative Analysis}

Whereas the results of quantitative analysis can show some interesting results and tendencies relating to the sample of respondents, the outcomes of the qualitative text analysis can be generalized to define the categories of consumer attitudes to shopping and shopping malls. A simple content analysis has been applied to scan the texts in the open ended questions. On the base of frequent responses or numerous mentions of the same problems, notions, 
cues etc. final categories were created. Even in this case, however, we can state a certain level of ambiguity. We can trace both extremes among shoppers: both nascent shopaholics and the shopping opposers of malls and shopping in general. In fact, we discern three main categories from the analysis of the responses: (i) mall enthusiasts, (ii) indifferent mall goers, (iii) mall opposers. The latter often consider shopping as a "necessary evil" which must be done "as quickly as possible"; as "provision of necessary items where there is no sense in prolonging this activity", we can also find many shoppers who come to the mall "to shop quickly and run away". These respondents in principle dislike the stressful environment of the mall, crowded by people, queues at the cashier desks, bad air-conditioning and unfriendly personnel.

Often it depends on the fact of what exactly is being bought and in which mood, thus food shopping is often considered as boring, in contrast to fashion shopping, book and furniture shopping, which are viewed as agreable. These respondents represent the second, transitional group which is disposed to confess that shopping may become a leisure activity, yet only sometimes and under certain conditions. "(shopping)... is a daily routine for me, I try to have it over as soon as possible. But sometimes, I really go 'hunting". Often also the notion of shopping as the act of love (Miller 1998) has been confirmed when respondents do not like shopping themselves, but they like to go with family, whose members like to shop, or they "shop for friends and family gifts rather than for me".

To the same extent as negative and ambivalent responses we can find positive reactions to shopping, from emotionally feeble opinions as "Shopping is a joy when I buy something new, a curiosity when I check the assortment and a nuisance when I shop too long" or "I do not like shopping as it is... (but) since I live in a village I enjoy shopping as a trip". Many respondents also stated that shopping represents relaxation, reposal, satisfaction with a good deal; here we can already trace the emergence of shopping as a true leisure activity (Timothy 2005) and a growing satisfaction with this type of leisure activity "a moment with my daughter for fashion, coffee and lunch". Also the conception of shopping as a "social enrichment" or "at least some communication with the outside world in a period when people spend too much time on the internet" can be interesting. Often the comprehension of shopping as retail therapy to alter mood (compare with the notion of a treat in Miller 1998) is found: "Often I go shopping as a reward for something or in sorrow". Consumers fully transformed to leisure shoppers then state a range of opinions from: "Shopping is a joy for me. It is relaxing and I like it very much", "It is the joy of new things", "I just like to visit the toy shops for adults" to opinions such as "It is a feeling of happiness", "It is my small addiction", "... shopping is for me an activity that I am looking forward to very much, which is exciting and it is an activity I cannot live without".

\section{Conclusion}

The results of the survey aimed at mapping the leisure shopping phenomenon in Czechia show that, similarly to the shopping format preference or development of the retail built environment, in the sphere of shopping behavior, Czech 
consumers are in a transitional phase. They quickly accept characteristics and trends of developed economies and the "western" models of shopping (Spilková 2003), but shopping does not stand for a solid alternative to traditional leisure activities. This is to a certain extent caused by the historical development and circa 40 years isolation of Czech consumers from the "normal" development of shopping behavior and a market economy. During these years of the totalitarian regime, traditional leisure acitivites were established as the only escape from the daily routine of the socialist state citizen (tramping, second housing, organized youth activities, sport etc.). On the other hand, it must be mentioned that in the transforming economies, thanks to their lagging retail environment development, the dynamics of the changes are, on the contrary, much faster and during the last 15 years we could witness a rate of development which took some 50 years in the developed countries of Western Europe.

It is obvious that the changes in shopping behavior in any postcommunist society were faster and more turbulent the later the market economy mechanisms were established. Czech consumers are now on the top of an imaginary consumption curve and are embracing all the new possibilities that shopping and the changing retail environment present. This is evidenced by yearly increasing sales of the biggest retailers, by increasing indebtedness of households to growing volumes of Christmas and Easter sales typical for U.S. society. It can be concluded that the changes in the shopping behavior of Czech consumers are to a great extent a natural phenomenon already experienced by the developed countries in the past decades. It is only a matter of time until shopping plays a greater role within the leisure activities of Czech consumers and will be promoted to the level of fun, a social and relaxing activity within a thriving material society.

\section{References:}

AC NIELSEN (2006): Hypermarkety - Nejvyšší počet ve střední Evropě jich má Česko. http:// www.mobchod.cz/vyzkum.php?itemid=2886.

BAKER, J., HAYTKO, D. (2000): The mall as entertainment: Exploring teen girls' total shopping experiences. Journal of Shopping Center Research, 7, No. 1, pp. 29-58.

BELLENGER, D.N., ROBERTSON, D.H., HIRSCHMAN, E.C. (1978): Impulse buying varies by product. Journal of advertising research, 18, No. 6, pp. 15-18.

BLOCH, P.H., RIDGWAY, N.M., DAWSON, S.A. (1994): The shopping mall as consumer habitat. Journal of retailing, 70, No. 1, pp. 70-71.

BREWIS-LEVIE, M., HARRIS, P. (2000): An empirical analysis of buying behaviour in UK high street womenswear retailing using the Dirichlet model. The International Review of Retail, Distribution and Consumer Research, 10, No. 1, pp. 41-57.

DENNIS, C., MURPHY, J., MARSLAND, D., COCKETT, T., PATEL, T. (2002): Measuring image: shopping centre case studies. The International Review of Retail, Distribution and Consumer Research, 12, No. 4, pp. 355-373.

DE VAUS, D. (2002): Surveys in social research, $5^{\text {th }}$ edition. Allen and Unwin, Sydney, 379 pp.

FINN, A., MCQUITY, S., RIGBY, J. (1994): Residents' acceptance and use of a mega-multimall: West Edmonton Mall evidence. International Journal of Research in Marketing, 11, No. 2, pp. 127-144.

FLICK, U., VON KARDOFF, E., STEINKE, I. (2004): A companion to qualitative research. Sage, London, $448 \mathrm{pp}$.

GILBOA, S., RAFAELI, A. (2003): Store environment, emotions and approach behaviour: applying environmental aesthetics to retailing. The International Review of Retail, Distribution and Consumer Research, 13, No. 2, pp. 195-211. 
GRAHAM, F.D. et al. (1991): Going to the mall - A leisure activity of urban elderly people. Canadian Journal on Aging, 10, No. 4, pp. 345-358.

GUY, C.M. (1998): Classifications of retail stores and shopping centres: some methodological issues. GeoJournal, 45, No. 4, pp. 255-264.

KOTLER, P. (1965): Behavioural models for analysing buyers. Journal of Marketing, 29, November, pp. 37-45.

KOWINSKI, W.S. (1985): The Malling of America. Xlibris: Bloomington, 415 pp.

LESSER, J.A., HUGHES, M.A. (1986): Towards a typology of shoppers. Business horizons, 29 , No. 6 , pp. 56-62.

MILLER, D. (1998): A theory of shopping. Cornell University Press, Ithaca, 180 pp.

NEWBY, P. (1993): Shopping as leisure. In: Bromley, R.D., Thomas, C.J. (ed.): Retail Change: Contemporary Issues. UCL Press, London, pp. 208-227.

REICHEL, J. (2009): Kapitoly metodologie sociálních výzkumů. Grada, Havlíčkův Brod, $184 \mathrm{pp}$.

SHOPPING MALL (2007). INCOMA Research, GfK Prague, Prague.

SHOPPING MONITOR (2005/06). INCOMA Research, GfK Prague, Prague.

SOJKA, J.Z., GIESE, J.L. (2003): Using individual differences to detect customer shopping behaviour. The International Review of Retail, Distribution and Consumer Research, 13, No. 4, pp. 337-353.

SPILKOVÁ, J. (2002): Nový fenomén nákupní centrum: behaviorální přístupy v pražském kontextu. Master thesis. Charles University, Faculty of Science, Prague, 140 pp.

SPILKOVÁ, J. (2003): Nový fenomén nákupní centrum a model formování nákupního chování spotřebitelské populace v transformačním období. Geografie, 108, No. 4, pp. 33-44.

SPILKOVÁ, J. (2008): Changing face of the Czech retailing in post-communist transformation: risks of extreme polarisation under globalisation pressures. In: Dostál, P. (ed): Evolution of Geographical Systems and Risk Processes in the Global Context. P3K, Prague, pp. 157-171.

SPILKOVA, J., RADOVÁ, L. (2011): The Formation of Identity in Teenage Mall Microculture: A Case Study of Teenagers in Czech Malls. Czech Sociological Review, 47, No. 3, pp. 565-586.

STONE, G.P. (1954): City shoppers and urban identification: observations on the social psychology of city life. American Journal of Sociology, 60, July, pp. 35-54.

SZCZYRBA, Z. (2005): Maloobchod v ČR po roce 1989. Univerzita Palackého, Olomouc, 126 pp.

THE FUTURE FOUNDATION (2006): Češi mají vysoké nákupní IQ. http://www.mobchod. cz/vyzkum.php?itemid=3367.

THOMAS, M.E. (2005): Girls, consumption space and the contradictions of hanging out in the city. Social and Cultural Geography, 6, No. 4, pp. 587-605.

TIMOTHY, D.J. (2005): Shopping tourism, retailing and leisure. Channel View, Clevendon, $222 \mathrm{pp}$.

UNDERHILL, P. (1999): Why we buy: The science of shopping. Simon and Schuster Paperbacks, New York, 255 pp.

UNDERHILL, P. (2004): Call of the mall. Simon and Schuster Paperbacks, New York, 240 pp.

WILHELM, W.B., MOTTNER, S. (2005): Teens and shopping mall preferences: A conjoint analysis approach to understanding the generational shift toward an experience economy. Journal of shopping centre research, 12 , No. 1, pp. 25-52.

WIRTH, L. (1938): Urbanism as a way of life. American Journal of Sociology, 44, No. 1, pp. 1-24.

\section{Shrnutí}

\section{ZROZENÍ ČESKÉHO FANOUŠKA NÁKUPNÍCH CENTER: PROMĚNA NÁKUPNÍCH ZVYKŮ Z UTILITÁRNÍHO NA REKREAČNÍ NAKUPOVÁNÍ}

Úvodní část článku seznamuje čtenáře s dynamickým vývojem odvětví maloobchodu v Česku během posledních dvou dekád, především pak s měnícími se nákupními zvyklostmi a spotřebním chováním české populace. Ve druhé části následuje krátké teoretické zarámování problematiky a představeny jsou typologie nakupování a nakupujících. Existuje mnoho různých klasifikací, přičemž tento článek nakonec vychází ze zjednodušené klasifikace podle Guye (1998), a to rozdělení nakupování na účelové nákupy a rekreační nakupování, tj. nakupování jako zábavu, jako formu volnočasové aktivity. 
Článek se dále věnuje trendu leisure či fun shopping, který se začal ve větší míře projevovat i mezi českými spotřebiteli. V létě roku 2010 byl proveden pilotní výzkum, který si kladl za cíl zmapovat rozsah tohoto fenoménu, pokusit se zjistit, zda nakupování může být v rámci české společnosti považováno za relevantní formu trávení volného času a vytipovat charakteristické vlastnosti spotřebitelů, pro něž je nakupování oblíbenou volnočasovou aktivitou. Šetření proběhlo formou elektronického dotazníku na internetu. Dotazník obsahoval otázky týkající se oblíbených maloobchodních formátů, nakupování v nákupních centrech a faktorech důležitých pro tato centra z pohledu respondenta, ale také otázky na trávení volného času. Součástí dotazníku byly samozřejmě také otázky mapující socio-demografické charakteristiky respondentů.

Pretestování dotazníku ukázalo potřebu upravit dotazníky, tak aby byly lépe pochopitelné pro respondenty, zejména pak v částech týkajících se emočních reakcí na nákupní centra. Dotazník byl tedy pro další kolo upraven a zjednodušen a bylo dosaženo míry návratnosti $26 \%$. Celkem se šetření zúčastnilo 224 respondentů. Zajímavé je, že $42 \%$ respondentů odpovědělo, že tráví svůj volný čas pasivně, tj. odpočinkem, u televize a podobně, aktivnímu trávení volného času se věnovalo $24 \%$ respondentů a cca $14 \%$ respondentů se věnovalo nějakým specifickým koníčkům. $6 \%$ respondentů uvedlo, že svůj volný čas nejčastěji tráví právě nakupováním a chozením po obchodech. Pouze $5 \%$ respondentů uvedlo, že nechodí nakupovat do velkých nákupních center. Ostatní se do nákupních center vydávají většinou 2 až 4 krát měsíčně (33\%), jedenkrát týdně (29\%), popř. jedenkrát měsíčně (24 \%). Stráví zde většinou 2 hodiny (37\%), něco kolem hodiny času zde tráví $21 \%$ respondentů a $15 \%$ zhruba 3 hodiny.

Pro $69 \%$ respondentů je nákupní centrum především prostorem, kde seženou vše, co potřebují, kde mají možnost dobrého výběru zboží a porovnání (61 \%), místem s kvalitními obchody (55\%). Zhruba stejně důležité jsou pak kategorie dostupnosti automobilem (43\%), fakt, že jsou zde k dispozici čisté toalety, možnost občerstvení a čisté prostředí (vždy cca $40 \%$ ), dostupnost MHD a rozumné ceny (obě $39 \%$ ). Jedna čtvrtina respondentů uvedla, že nákupní centrum je pro ně hezkým místem, kde rádi tráví čas, cca $13 \%$ respondentů si pak myslí, že nákupní centrum je živé, vzrušující místo.

Přesto, že výsledky pilotní studie můžeme považovat pouze za orientační a s omezenou vypovídací hodnotou, již na první pohled je jasné, že čeští spotřebitelé se stále nachází na přechodu mezi dvěma fázemi nákupního chování (viz Spilková 2003). Plně se adaptovali na maloobchodní prostředí s velkoplošnými formáty, menší frekvencí nákupů a na velká nákupní centra, která pro ně představují nejen cíle pro nakupování, ale také oblíbená místa společenského setkávání a trávení volného času. Na těchto centrech však stále oceňují především jejich praktické vlastnosti jako je možnost nákupu pod jednou střechou, možnost výběru a porovnání zboží, dostupnost automobilem a MHD a vybavenost centra doplňkovými službami. Zcela jasně se však vyděluje skupina nakupujících, pro které je nakupování více, stává se pro ně formou trávení volného času, životním stylem a nákupní centrum se stává přirozeným středobodem jejich akčního prostoru.

Obr. 1 - Preference hlavního nákupního místa českých domácností v letech 1998-2010. Obrázek ukazuje měnící se preference pro výběr hlavního nákupního místa českých spotřebitelů v období mezi rokem 1998, kdy se teprve začaly objevovat velké maloobchodní formáty, a rokem 2010. Zcela jasně je zřetelný posun $\mathrm{k}$ oblibě velkoplošných a více komplexních forem maloobchodních zařízení, zatímco popularita tradičních, menších, forem maloobchodních prodejen klesá. Zdroj: INCOMA Research, GfK Prague.

Authors'affiliation: Charles University in Prague, Faculty of Science, Dpt. of Social Geography and Regional Development, Albertov 6, 128 43, Praha 2, Czechia; email: spilkova@natur. cuni.cz.

Initial submission, 29 December 2010; final acceptance 20 June 2011.

\section{Please cite this article as:}

SPILKOVÁ, J. (2012): The Birth of the Czech Mall Enthusiast: The Transition of Shopping Habits From Utilitarian to Leisure Shopping. Geografie, 117, No. 1, pp. 21-32. 